OPEN ACCESS

Edited by:

Clara Irazabal,

University of Maryland, College Park,

United States

Reviewed by:

Fernando Lara,

University of Texas at Austin,

United States

Jana VanderGoot,

University of Maryland, College Park,

United States

${ }^{*}$ Correspondence:

Walter Timo de Vries

wt.de-vries@tum.de

Specialty section:

This article was submitted to

Urban Greening,

a section of the journal

Frontiers in Sustainable Cities

Received: 22 February 2021

Accepted: 06 May 2021

Published: 11 June 2021

Citation:

de Vries WT (2021) Urban Greening

for New Capital Cities. A Meta Review.

Front. Sustain. Cities 3:670807.

doi: 10.3389/frsc.2021.670807

\section{Urban Greening for New Capital Cities. A Meta Review}

\author{
Walter Timo de Vries* \\ Faculty of Aerospace and Geodesy, Technical University of Munich, Munich, Germany
}

In light of the discussions on relocating the capital city of Indonesia to a new location in Kalimantan, and create a new green capital city (referred to as IKN), the purpose of this meta-review paper is learn from experiences from other relocations of capital cities and creations of green cities in the world. Specific emphasis is hereby given to urban greening and gentrification. This article applies a meta-analytical approach by connecting the basic tenets of the $8 \mathrm{R}$ framework of responsible land management to assess the pros and cons of a selected set of capital city relocations and green cities. From the comparison, it is possible to generate general recommendations for Indonesia's new green capital city. The comparison reveals that each of the selected cases falls short in one or more aspects of the $8 \mathrm{R}$ framework. In all cases, constructing green capitals requires a mixed and integrated land use planning, a transparent regulatory framework toward land use control, extensive consultation with both local, national and international stakeholders, and participation with local residents. Only under these conditions, one can ensure ownership, respect and trust in the decision. The quandaries highlight the complexity of capital city relocation and green city creation. The originality lies in the specific land management framework perspective and discursive analysis of documented discourses on constructing new capital and green cities. This provides new options for devising and extending regulatory guidelines and for assigning responsibilities for such new mega-endeavors. Given the conceptual and discursive character of the paper, a limitation of the approach may be that there are no specific empirical data collected, yet several recommendations for further research include expanding the boundary work between the land management, the spatial planning and governance domains.

Keywords: urban greening, land management, Indonesia, capital city, responsible land management, gentrification

\section{INTRODUCTION}

History shows that capital cities play an important role in the image, representation and identity of a country (Lazar, 2005). In most cases, these capital cities are also the largest and/or most populated cities of these countries, but there are also remarkable exceptions, such as Canberra in Australia, Washington in the USA, The Hague in the Netherlands and Ottawa in Canada. When the designation of the capital city needs to be changed, for example after a major revolution or when aiming to establish a new political ideology, countries tend to embark on relocating and re-establishing their capital city. This process has taken place in multiple parts of the world, and recently especially in developing countries and countries in transition. In the western world, a notable example of relocations of capital cities include the relocation of Berlin to Bonn, and more recently back to Berlin again. This obviously has to do with political and ideological changes, 
but also with the establishment of a new meaning and alternative self-image both nationally and internationally (Cochrane and Jonas, 1999; Eckardt, 2005). Additionally, Brazil for example embarked in the late 1950s on establishing their new capital Brasilia based on a modernist, technologically driven ideal that one could construct a new town based on rigid plans and the idea of shaping a new future from scratch (Rawat, 2005; Rossman, 2018). Many other countries followed since then in relocating and reconstructing their capital city ideals, such as Pakistan (Karachi to Islamabad), Nigeria (Lagos to Abuja), Malawi (Zomba to Lilongwe), Tanzania (Dar Es Dalaam to Dodoma), Kazakhstan (Almaty to Astana). Post-independent countries often decide to re-locate their capital city to a new location in order to reflect independence, reflect a new social representation of all peoples of the country, and to create a new national symbolic location whereby the center of power is in the center of the country.

All these justifications come with serious counter-arguments given documented empirical evidence. The new capitals suffer frequently from non-organic spatial designs, biased and non-harmonic social representations and either uncontrolled expansion (e.g., Abuja) or extremely limited expansion (e.g., Dodoma). In both cases, such capitals face serious development and livability problems. One of those problems in particular concerns different forms of gentrification and social segregation. Momoh et al. (2018) and Momoh and Benachir (2018) list gentrification as one of the emerging challenges in Abuja as a direct result of the inability to align the rural-urban migration to the design and monitoring of an urban development master plan. Lauriano (2015) reports that gentrification in Brasilia is largely the result of its original design for inhabitants with cars, and limited attention for public transport for those with more limited budgets. The direct consequence of this is a serious housing problem, which do not relate to land scarcity, but to property and income scarcity. Kampamba et al. (2018) describe the process of gentrification in Gaborone due to growing demand for middle-income housing leading to increasing eviction of lower-income residents. Seitzhanova and Nagy (2018) argue that some form of gentrification was in fact a necessary requirement for the new capital city Astana to grow and attract tourist for both the city itself as well as the surrounding region. In all these cases of capital city development, gentrification is primarily related to housing and new construction developments and not so much to environmental concerns.

A relatively historically new justification for a relocation of a capital city is to create a green city, or even the greenest city of the country, as a representation for new ecologically and environmentally friendly policies. Such contemporary knowledge and insights in responsible and sustainable city development are for example noticeable in contemporary reports on Malaysia's Putrajaya (Abdullah et al., 2020), South Korea's smart energy city Sejong (Yoon and Shin, 2019), or a "biophilic" capital city - one "full of nature" for Egypt (Nasreldin and Abdelfattah, 2020). Such greening visions are also playing a role in Indonesia's ambition for its new capital city - designed to be located in Kalimantan - which should become the greenest, smartest and sustainable capital city in the world. There are currently various designs for this new capital city, but it remains relevant to assess how and when such an ambitious goal is achieved.

This research should thus support the further choices in the design and implementation of the relocation of the Indonesian capital city, referred to as IKN (Ibu Kota Negara). As the current capital Jakarta is highly populated and is frequently suffering from environmental problems, such as floods, seeking an alternative locations for the administration has long been on the Indonesian agenda. How such intentions should become reality and what such intentions imply is the key objective of this article. We hypothesize that previous examples contain a certain degree of similarity, which can derive recommendations for future capital and green city designs. We further hypothesize that inclusion and diversity of such cities are vital. The main aim was not to judge the rightness or wrongness of the relocation of the capital in Indonesia specifically, but to support the decision makers in Indonesia in deducting which possible problem might arise, so that they could prepare for this.

This article starts by evaluating the variations in definitions and concepts of what constitutes either a capital city or a green city and what a number of design criteria are for green capital cities. The subsequent section explains the socalled 8R framework of responsible land management, which allows an assessment and comparison of capital and green city development. We apply this framework on evaluating and assessing 3 new capital cities and 3 awarded green cities, with the aim to generate recommendations for the plans of Indonesia. The Conclusion section provides a synthesis of the findings and recommendations for further continued research on this topic.

\section{DEFINING CAPITAL AND GREEN CITIES}

The fundament for this research lies in defining what actually constitutes both a capital city and green city. There are differing concepts related to both of these terms, which are dependent on location, ideology, culture and strategic planning. These differences influence the choices for the construction of a new capital city, which needs to be green and/or smart. The investigation relies on evaluating previous examples of both previous capital city relocations and designs and of evaluating characteristics of other cities that are supposedly green or perceived as green. The comparison of these examples relies on both the theoretical concepts combined with practical and professional choices made in different locations. The goal of this comparison is to derive recommendations for future designs and assessments of capital and green cities.

\section{Varieties of Capital Cities}

There are various ways to look at what constitutes a capital city. The pragmatic definition of Rossman (2018) is the location which represents the ideal image of the country and country's history. It is for example for this reason that a number of capital city names are the same as the country names (e.g., Mexico City, Panama City, Brasilia, Tunis). Hall (2006) distinguishes 7 varieties of capital cities. First, Multi-functional capitals (such as London, Paris, Madrid) combine and host all possible national-level 
functions besides hosting the seat of the government. Usually they represent centralized public administrative and commercial systems, and are locations for performative functions, such as national ceremonies, event and parades. Secondly, the category Global capitals (e.g., Tokyo) represent cities, which conduct supra-national functions in politics and commercial life. Thirdly, political capitals (e.g., The Hague, Bonn, Canberra), established as locations where government conduct their activities, yet not necessarily the centers of commercial life. Fourthly, former capitals, being cities (St. Petersburg, Rio de Janeiro) which still maintain an international visibility and appearance as de facto capitals, yet having lost this official status. Fifthly, exempirical capitals (e.g., Vienna, Lisbon). Despite having lost the status of imperial centers they still act as cultural and commercial centers. Sixtly, provincial or State capitals (e.g., Munich, Sydney, Toronto). These are often cities, which function as metropolitan areas with large territorial influence both regionally and nationally. Lastly, super capitals (e.g., Brussels, Geneva, New York), which host international and multilateral organizations and thus act as capital cities with international diplomatic representations. Finally, large, federal and unified countries can have multiple capitals represented in historical and culture. For example in India the city Shimla represents the Himalayan hill station that was the "summer capital" of British India; Kolkata, earlier known as Calcutta, was the former capital of the British empire in India; New Delhi was the capital of several Islamic dynasties that ruled Northern India, including the Mughals, until it became the imperial capital in 1911 - when Calcutta lost that status - and was then developed as independent India's capital; and Chandigarh is a provincial capital with major post-Independence modernist implications:

From a critical spatial economic perspective one could also define capital cities as those cities where financial capital accumulates, usually in the form of urban real estate, and often at the expense of peripheral areas, combined with relocation and/or eviction of poorer people.

\section{Varieties of Green Cities}

As diverse as capital cities are also labels and characteristics of green cities, also associated with the labels of eco-cities, sustainable cities, climate-neutral cities, car-free cities or even smart cities. The qualification "green" can relate to various types of ideals and norms. According to Breuste (2019), the green can relate to ecological alternatives, and/or the technical improvements, such as the reliance on renewable energy. A city with low greenhouse gas emissions is furthermore considered green, as well as a city with plenty of green spaces (Kahn, 2007, Glaeser and Kahn, 2010). In addition, a city with dense and highly accessible public transport systems, bicycle paths and car-free pedestrian areas are also seen as green (Beatley, 2012). Albino and Dangelico (2013) refer to a Green Cities Practices Matrix to compare the greenness of cities, based on the characterization of green urban practices, and connected to green economy principles. Hereby green relates to three types of environmental foci: material (such a use of recyclable, biodegradable, environmentally neutral materials), energy (use and production of renewable energy; reduction of fossil fuels), and pollution (does not pollute or reduces pollution). In her book LO-TEK Design by Radical Indigenism, Watson et al. (2020) argue that tribal communities, seen by many as primitive, are highly advanced when it comes to creating systems in symbiosis with the natural world. Green cities in this book are seen as cities designed in such a way that they make better use of the natural qualities in terms of ecosystem services. Finally Breuste et al. (2020) provide the following working definition of green cities: the Green City is a city, where all forms of nature-living organisms, biocoenosis, and their habitats-are highly significant components of green infrastructure. In a Green City, these forms of nature are preserved, maintained, and extended for the benefit of city residents. Urban nature is an ideal provider of services, and a key concept for city development. To a large extent this makes a green city a metaphorical vision for preserving existing nature while adapting it optimally for residents in cities. Such a city design must ensure that the quality of life improves.

\section{Green Capital City Awards}

Globally there are various kinds of greenest or most-ecofriendly award lists, which are arguably also biased toward the interests and the economic or political ideals of the designers of such lists. Although the word "capital" is used in a different sense as described above, the European Commission has a socalled "European Green Capital" award", based on predefined environmental criteria. Awarded yearly since 2010, it is an incentive for European cities to adapt to greener practices and/or to design new area, which better fit the awards' criteria. Although also aimed symbolically as uniting Europe under one green flag, the award practically judges and assesses air and water quality, noise emissions, production and handling of waste, biodiversity, use and production of alternative and renewable energies, and mobility. The subsequent European green capitals have been Stockholm (2010), Hamburg (2011), Vitoria-Gasteiz (2012), Nantes (2013), Kopenhagen (2014), Bristol (2015), Ljubljana (2016), Essen (2017), Nijmegen (2018), Oslo (2019), Lissabon (2020), Lahti (2021), Grenoble (2022). The subsequent awards reflect certain design principles and blueprints for other cities to commit to further action, to showcase and encourage exchange of best practices. In this way, such examples might also be useful for the capital design of Indonesia amidst a tropical forest area.

The C40 is a network of the world's megacities committed to addressing climate change. C40 supports cities to collaborate effectively, share knowledge and drive meaningful, measurable and sustainable action on climate change. The Arcadis Sustainable Cities Index ranks 100 global cities on three dimensions, or pillars, of sustainability: People, Planet, and Profit. These represent social, environmental, and economic sustainability to offer an indicative picture of the health and wealth of cities for the present and the future. Australia's Sustainable Communities - Tidy Towns and Sustainable Cities awards programs encourage, recognize and reward local communities, councils, businesses and schools for their outstanding efforts to reduce litter, increase recycling and beautify and improve their local environment. All-in- all such

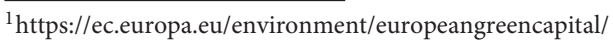


TABLE 1 | Selected cities for researching character of capital green cities.

\begin{tabular}{ll}
\hline Capital cities & Green cities \\
\hline Brasilia - Brazil & Lahti - Finland \\
Putrajaya - Malaysia & Vancouver - Canada \\
Sejong - South Korea & Masdar - UAE \\
Berlin - Germany & Birmingham - UK \\
\hline
\end{tabular}

awards also reflect best practice and guidelines for further greening of cities.

There are also lists of the worst and least green city. One could argue that most of these lists are also not completely neutral, and often reflect certain interests. According to the IQAir ranking Hotan, China ranks as the most polluted city in the world, and Orzesze in Poland as the most polluted in Europe $^{2}$ Research conducted by Good Move ranked cities across the UK based on the degree of eco-friendliness, and lists Birmingham as the least eco-friendly ${ }^{3}$. The degree to which this is true is somewhat subjective. Criticasters would argue that many of these competitive lists are often also marketing tools for cities itself as well as for normative of political (mostly neoliberal, western) ideas (Angotti and Irazábal, 2017). The least green city may not reflect the ideal global city in the exes of some, despite perhaps having some other positive qualities of cities, such as being democratic, authentic or independent. It is therefore that one has to include a critical evaluation in the use of comparative frameworks.

\section{Review of Documented Cases}

The analytical and conceptual investigation relied on comparing and synthesizing documented experiences and learning lessons from previous examples of both previous capital city relocations and designs. Unlike a full systematic review a meta-review relies more on a justified sampling and selection strategy based on qualitative rather than quantitative grounds (Timulak, 2014). Hence, there was an investigation of characteristics of other cities which were supposedly green or perceived as green. The comparison of these examples relied on both the theoretical concepts combined with practical and professional choices made in different locations. The goal of this comparison is to derive recommendations for future designs and assessments of capital and green cities. Table 1 presents the cities which were reviewed.

The choice for Brasilia was because its characteristics of its choice of re-location is similar to the planned location of the new capital of Indonesia, given its territorial centrality and its surrounding tropical rainforest. The current location had originally only some 1,000 indigenous residents, but the current population is estimated at more than 4,7 million (figures of $2021)^{4}$. The relocation of the capital from Rio de Janeiro to this location drew on several arguments, including developing

\footnotetext{
${ }^{2}$ https://www.forbes.com/sites/emanuelabarbiroglio/2020/02/29/cities-inpoland-and-italy-among-europes- 100 - most-polluted/?sh=490b662c58fd

${ }^{3}$ https://goodmove.co.uk/britains-green-cities/ (last date of access 23 March 2021).

${ }^{4}$ https://worldpopulationreview.com/world-cities/brasilia-population (last date of access 21 February 2021).
}

and colonializing the hinterland, providing more security for administrator and residents and creating a new identity reflecting independence (Grimes et al., 2016; Bravo, 2019; Faria and Pescatori, 2019).

The choice for Putrajaya is its similarity in culture, geography and history. The location was on former oil palm and rubber plantations. Moreover, similar to the new capital of Indonesia, the Malaysian government created an idea to develop a capital primarily for an administrative function, aimed to host all of Malaysia's federal government ministries and national level civil servants, and all diplomatic activities for the country. Gradually the idea also developed into a more symbolic capital reflecting independence, modernization and Muslim culture.

Since 2012, South Korea accepted to allocate Sejong as the administrative capital, with a plan to relocate government functions outside of Seoul. Until today, South Korea has a twocapital model. Seoul has long been the official capital and the economic and cultural center of the country, but Sejong City is now the administrative capital where many of the government's most important agencies are located. The choice for looking at Sejong in view of assembling recommendations for Indonesia is 3 -fold. Firstly, the governments has generated experience in the relocation process. Since 2012, the government of South Korea has relocated numerous ministries and agencies to Sejong, even though a number of organizations still reside in Seoul. Secondly, the character of the city as administrative center instead of creating a multi-functional city may resemble the phased-based approach in Indonesia. Thirdly, Sejong has especially become well-known internationally as one of the first ICT-driven smart city called Ubiquitous Cities (U-City), and one of the full-scale greenfield development models of a future city armed with cutting-edge ICTs (Leem et al., 2019). This is an ideal, which is also aspired by the Indonesian government. How this turns into practice may be insightful.

Berlin is a relevant case in the context of the IKN because of its recent transition as the new capital combined with enormous investments. Although the choice of Berlin as capital of the country has never been seriously disputed, not even before the fall of the wall, the image of Berlin suffers from its past. Konrad Adenauer, the first chancellor of West Germany after the Second World War, chose Bonn as temporary capital, assuming that it would be possible to relocate in case of a reunification (Leadbeater, 2016). After the "Hauptstadtbeschluss," the formal decision to opt for Berlin as new capital, the city faced however two major problems (Báčová, 2012; Rossman, 2018). First, the city's clear connection Germany's national-socialist past, reflected in the once again centralized structures (Campbell, 1999). A Germany with Berlin as its capital can be matched with the Germany from the Nazi-past as it again represents a strong and centralized state, that was the basis for quick takeover of power by Adolf Hitler (Campbell, 1999). Secondly, there was a tremendous pressure on ensuring the construction of appropriate symbolic artifacts representing the identity and memory of the city (Campbell, 1999; George et al., 1999; Rossman, 2018). Many buildings from the Nazi and communist past were destroyed and provided space for adequate memorial buildings, but most of these were equally praised and criticized. 
New Berlin differs from its past states: German federalism has decentralized the city and stressed institutional separation (Campbell, 1999). Second, was the high expectation on appropriate culture of memory in the city (Campbell, 1999; George et al., 1999; Rossman, 2018). Many buildings from the Nazi and communist past left plenty of space for adequate memorial building. Germany, obviously, wanted to erect a capital that well-cared for its past, and even hoped to integrate a combination of western capitalism and eastern socialism in the cityscape and the whole country after reunification (Campbell, 1999). For many the city ever has been the symbol of reunification (Cochrane and Passmore, 2003). It is welllocated and can serve for the country's economic rebalancing by attending to east-German unemployment rate, and panEuropean unification (Bedford, 1992; Faggio et al., 2018). Without disregarding Bonn, where six out of 10 ministries have remained, also for fear that the city would otherwise perish, the reintroduction of Berlin could contribute to the reconstruction of an entire nation and demonstrate solidarity between East and West (George et al., 1999; Leadbeater, 2016; Rossman, 2018). However, the decentralization measure alone, and the associated communication between Bonn and Berlin, is estimated to cost around 5 million euros annually (Rossman, 2018).

The most recent green European capital (of 2021) is Lahti in Finland, the capital of the Päijänne Tavastia region of Finland, has a population of 119,068 . Lahti lies approximately 100 kilometers to the northeast of Helsinki, the capital city of Finland on the southern bay of Lake Vesijärvi. The rapid industrialization in Lahti in the last decades led on the one hand to significant economic growth for the region, but also to significant environmental challenges, such as the eutrophication of Lake Vesijärvi and a higher dependency on cars in the city center. This prompted the city government to come up with more comprehensive green policies, involving multiple stakeholders, directly affected by the negative ecological impacts, such as the Lake Vesijärvi project, where university research groups, residents, local companies and the City work together to improve the lake's condition. Despite the relatively small size as compared to most major European cities and country capitals, the experiences of Lahti are highly relevant for the construction of a new city in a forest area. Additionally, since the current plan of the IKN is an upgradable growth, in different phases, it will need to start with a relatively small starting territory. The description on the website of the European Green Capital states that in Lahti, $99 \%$ of people live within $300 \mathrm{~m}$ of green urban areas. The city enables its inhabitants to enjoy nature in many different ways, offering leisure activities such as skiing, fishing and wild berry and mushroom picking. The city has a clear vision for green growth and eco-innovation. The Lake Vesijärvi and the Grassroot projects, for example, promote the reuse and sharing of public spaces in the city, making these spaces available to rent. These kinds of ideas enable the development of new projects with strong citizen involvement.

Vancouver's greenest action plan (GCAP) of the City of Vancouver, originating from 2009, is comparable to the IKN in the sense that the plan aimed at becoming the greenest city in the world by the year 2020. Such high ambitions together with the action items in the plan may be relevant in constructing larger metropolitan areas. Vancouver has approximately 600,000 inhabitants. Remarkably enough Vancouver, the largest city in British Colombia is not the capital of that Province, which is the less populated Victoria ( $\sim 335,000$ citizens), but there were plans to move the capital from Victoria to Vancouver ${ }^{5}$ In any case, the greenest action plan led for example to winning the C40 cities award at the 2015 Paris Climate summit ${ }^{6}$ The GCAP outlines the following 10 discrete goals: green economy, green buildings, green transportation, zero waste, access to nature, lighter ecological footprint, clean water, clean air, local food.

Abu Dhabi, one of the emirates of the United Arab Emirates, initiated the construction of Masdar City. The location is $17 \mathrm{~km}$ from Abu Dhabi International Airport, in the middle of severe desert conditions. To build an environment with many greenfield conditions seems therefore at first extremely ambitious. Launched in 2006, Masdar City aimed to be a model of sustainability and of urban planning itself (Cugurullo, 2013). Developed by the stateowned Mubadala Development Company, the aim has been to combine smart technologies with ecologically-balanced integrated urban development, including self-generated energy availability through solar, energy efficiency and other zerocarbon features in subsystems such as transportation, civic utilities, physical infrastructure, water management, waste management (Sankaran and Chopra, 2020). The carbonneutrality is remarkable in a country which is rich in fossil fuel, and whose GDP depends for $70 \%$ on the export of oil and gas. Nevertheless, the city should become home for 40,000 people and 50,000 daily commuters. The choice to look at Masdar City as an example for the IKN is relevant because it is also a city built from scratch aiming to be energy neutral and not depending on natural resources from the vicinity.

To understand if the greening policies of highest and lowest ranked green cities are essentially different we also add Birmingham as the least eco-friendly city in the UK. The question hereby is if not being green also corresponds to not being participative, democratic or socially just for example, or whether not being green in the eyes of the ranking is instead a political branding issue. In fact, the city council of Birmingham developed a "green living spaces plan" in 2013 (Birmingham City Council Development Directorate, 2013) based on the greening principles of prosperity, fairness and good health, a city in which to work, live and enjoy by being more efficient with scarce resources and a city for the delivery of green finances and business - so-called green urban entrepreneuralism.

\section{R Framework of Responsible Land Management}

The analytical lens of the investigation was the $8 \mathrm{R}$ framework of responsible land management (De Vries and Chigbu, 2017). The $8 \mathrm{R}$ framework was derived from international

\footnotetext{
${ }^{5}$ https://dailyhive.com/vancouver/bc-capital-victoria-vancouver-legislaturemove

${ }^{6}$ https://www.straight.com/news/591306/vancouvers- greenest-city-action-planwins-c40-cities-award-paris-climate-summit
} 
TABLE 2 | 8 R aspects of the 8R framework of responsible land management.

\begin{tabular}{|c|c|}
\hline & Looking at questions such as ... \\
\hline Responsive & $\begin{array}{l}\text { Including needs, requests, long-term views of stakeholders } \\
\text { Addressing urgency of need }\end{array}$ \\
\hline Resilient & $\begin{array}{l}\text { Ensuring or creating the sustenance of societal structures } \\
\text { Avoiding major disruptions }\end{array}$ \\
\hline Robust & $\begin{array}{l}\text { Based on solid mechanisms } \\
\text { Not leading to fundamental change or disruptions }\end{array}$ \\
\hline Reliable & $\begin{array}{l}\text { Decisions are trusted or are based on trust or creating trust by } \\
\text { stakeholders and directly affected citizens }\end{array}$ \\
\hline Respected & $\begin{array}{l}\text { Decisions and actions are valued positively by stakeholders and } \\
\text { directly affected citizens } \\
\text { Decision makers are seen as appropriate leaders or managers }\end{array}$ \\
\hline Retraceable & $\begin{array}{l}\text { All steps are documented, so history can be reconstructed } \\
\text { At all times it is possible to see which steps have been taken by } \\
\text { whom, and what still needs to occur }\end{array}$ \\
\hline Recognizable & $\begin{array}{l}\text { People can identify with the decisions; there is ownership of the } \\
\text { project or intervention }\end{array}$ \\
\hline Reflexive & $\begin{array}{l}\text { At regular points in time there are moments at which the } \\
\text { rightfulness or appropriateness is re-evaluated or re-assessed }\end{array}$ \\
\hline
\end{tabular}

literature and multilateral conventions and guidelines on what is considered "responsible" public administration, land governance and spatial planning (Bourgon, 2007; Cooper, 2012; FAO, 2012). The resulting assessment framework aims at analyzing and classifying differences among cities and to derive practical recommendations for improvement. This $8 \mathrm{R}$ framework uses 8 aspects which qualify land interventions, evaluating whether these are responsive, robust, respected, recognizable, resilient, reliable, reflexive, and retraceable. These aspects are largely self-directed, but during the evaluation, one can also combine these if certain artifact or manifestation justify this. During an $8 \mathrm{R}$ assessment, one evaluates for each aspect the degree to which these are present in either the structure, processes or impact generation of the associated land intervention. Such an assessment can be both qualitative and/or qualitative (Amekwa et al., 2018). Part of then assessment also include elements of being participative, inclusive or democratic, which are crucial for spatially just urban planning (Caldeira and Holston, 2015). Specifically, the aspects of responsiveness, respect and reliability address the extent to which these values are present in the preparation, execution and maintenance of such interventions. Tables 2, 3 list the type of questions, which are relevant for each of the $8 \mathrm{R}$ aspects.

Like any assessment, an $8 \mathrm{R}$ assessment cannot be fully neutral, or free from any assumed epistemology and axiology. It is best to clarify this from the start in order to position the assessment in this context. To a large extent the $8 \mathrm{R}$ framework is an engineering heuristic rooted in an engineering epistemology (Grimson and Murphy, 2015), aimed at practicality, experience and iterative revision of old and new interventions. The ultimate goal of the $8 \mathrm{R}$ assessment is not to rank the chosen case cities in a list of good and bad, or to compare cities in develop or developing countries but to derive practical suggestions for spatial interventions,
TABLE 3 | The aspects against which the 8Rs are reflected.

Looking at questions such as ...

\begin{tabular}{|c|c|}
\hline Structures & $\begin{array}{l}\text { Validity and functionality of institutional structures to manage the } \\
\text { project or intervention } \\
\text { Validity and functionality of technical structures needed for } \\
\text { the interventions }\end{array}$ \\
\hline Processes & $\begin{array}{l}\text { Logic of process sequence } \\
\text { Appropriateness of individual steps Need for parallel processes } \\
\text { / steps }\end{array}$ \\
\hline $\begin{array}{l}\text { Outcomes } \\
\text { and impacts }\end{array}$ & $\begin{array}{l}\text { Appropriateness of results, changes } \\
\text { Visibility and proof of results, changes }\end{array}$ \\
\hline
\end{tabular}

prevention of technical and social conflicts, and planning of early mitigation measures.

\section{RESULTS AND DISCUSSION}

The analysis of the abovementioned-documented cases relied on the $8 \mathrm{R}$ framework. The assessment involved reflecting on the degree to which each of the 8 R's were present and/or significant (positively or negatively) in each of the respective cases. This was a qualitative assessment in view of the questions for each of the 8 R's (summarized in Table 4). More detailed questions could be added.

The discourse on the pros and cons of Brasilia as a novel city developed from scratch is broad. An often-framed critique is that the design of the city followed a now outdated image of what a city should look and feel like. An overall impression of emptiness one of the expressed critiques, whereby all of the government buildings were similar and located based on geometric principles. The residential "superquadra," or superblocks, intended for government workers and their families were outside of the government areas. Each superquadra looked alike, containing six-story residential towers in a park-like setting as well as a school, playgrounds, shops, recreation fields, and community spaces. Its original conception was egalitarian, providing equal opportunities to all citizens, without any preferences or differences. This vision intended to foster social change, in particularly handling the Brazilian socio-economic segregation (Rezende and Heynen, 2020). Various scholars have however highlighted that segregation continued in all sorts of forms. The original plan for Brasilia did not anticipate lowincome housing for example, suggesting that the city would not host and reflect all classes of society. Expansion of the city into peripheral areas of the region due to Rapid population growth however, enhanced the unplanned and informal character of the region. More generally, top-down land governance led to socio-spatial fragmentation (Costa and Lee, 2019). From an 8R perspective, one could say that the original design was not in accordance with needs of citizens, or at least not in line with consultative processes, hence not responsive. The subsequent continuing critique on land use planning and land use control, lack of multi-functional use of space suggests problems regarding the robustness of the design and subsequent policy measures. In addition, the continuing socio-spatial segregation coupled with 
TABLE 4 | Summary of 8R, urban greening and gentrification findings for each selected city.

\begin{tabular}{|c|c|c|}
\hline City & Did well on aspect & Concerns exist with aspect \\
\hline Brasilia & $\begin{array}{l}\text { Retraceability (many of the earlier } \\
\text { plans are preserved and } \\
\text { documented). } \\
\text { Resilience (new societal activities } \\
\text { emerge beyond the original } \\
\text { design and societal ownership } \\
\text { and belonging emerges with } \\
\text { time). }\end{array}$ & $\begin{array}{l}\text { Responsiveness (due to lack of } \\
\text { participation), Recognizability } \\
\text { (segregation and crime have } \\
\text { increased), Robustness (too } \\
\text { rigid land use planning } \\
\text { processes). }\end{array}$ \\
\hline Putrajaya & $\begin{array}{l}\text { Respect, recognition and } \\
\text { reliability (society supports and } \\
\text { trusts the decision to relocate } \\
\text { and people can identify } \\
\text { themselves with the decision). }\end{array}$ & $\begin{array}{l}\text { Responsiveness (limited direct } \\
\text { involvement of citizens). } \\
\text { Robustness (given the side } \\
\text { effects of rapid uncontrolled } \\
\text { property price increases). }\end{array}$ \\
\hline Sejong & $\begin{array}{l}\text { Respect (as there was both } \\
\text { political and societal support) }\end{array}$ & $\begin{array}{l}\text { Resilience. (legal) robustness } \\
\text { (as the legal foundation for the } \\
\text { relocation was declared } \\
\text { unlawfull and the ICT-supported } \\
\text { processes did not increase } \\
\text { efficiencies. }\end{array}$ \\
\hline
\end{tabular}

Berlin

Lahti

Vancouver

Masdar City

Birmingham
Recognition, because most Germans agreed with the relocation.
Robustness and respect are at stake given the high costs for the reconstructions and the emerging gentrification. Responsiveness, because Bonn actually had an operational government infrastructure.

Respect and retraceability (given Robustness may be a concern the documented evidence needed for the award). Recognition and resilience (given arise. the high number of citizen initiatives).

Reflexiveness given the commitment to lessons learned and proposed modifications for the future.

Respect and recognition structures (citizens agree with the overall goals).
Eventually it turned into a car-favored city design. Given its close proximity to the old capital, similar types of gentrification emerged.

(unvoluntary) displacement is likely to occur.
Spatial design and associated rigidly, leading to car-biased/favored urban structure.

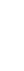

Robustness may be a concer
if the city expands and/or if certain unforeseen inequalities

Upgrading and greening close to the waterfront may lead to gentrification.

New types of businesses and SMEs may be required to reduce the spatial economic inequalities.

Resilience and recognition processes and outcomes (people do not live by the goals).

Gentrification occurring in multiple ways especially in re-development and transit oriented development strategies.

Risk of inequality and approach over time) Resilience (as the developed technologies have become profitable and bankable over time).

Responsiveness derived from the greenerbirmingham people's manisfesto. inaccessibility (given that most of the town still empty).

need was addressed at the

start).

Recognition and respect (as at the project is primarily for profit and not for people).

Resilience and robustness are Social housing policies are still at stake because social and environmental justice and equity inequalities. are not aligned.
Enhance reflexivity in subsequent spatial decision making and implementation phases. Create sufficient public transport for all levels of society. Provide space and time for bottom-up new socio-economic initiatives and a sense of ownership.

Carefully plan and control unintended socio-economic side effects of the relocation. Seek broad public support.

There is a need to create more functions and facilities in order to attract a critical mass of people and increase its livability.

A new capital will have to accept having to deal with the collaborating with functions and processes from the old one. Redundancies may emerge. Displacement must be taken seriously.

Maintain existing infrastructure from old capital which is operational in order to reduce immediate costs.

Carefully reflect on costs for monuments.

Greening implementation work best when applying a reflexive and upgradable strategy supported by a variety of citizen initiatives.

Broaden the spectrum of business and SMEs.

Ensure that ambitions and reality remain in sync. Do not strive to be the best only for the international rankings.

Align redevelopment strategies by creating more equal access to housing for all.

Rethinking the original approach after a number of years of construction is crucial.

More holistic approach which aligns greening and social and spatial justice approaches is necessary. 
the uncontrolled migration suggests a lack of recognition of structures and processes. Furthermore, from a land management perspective there were strict limitations on building height, land use, and rooflines. Transportation was centered around cars, which was at the time of its design the new, exciting mobility technology. This suggests limited space for redesign, renovation and hence limited reflexivity.

On the other hand, a number of authors also highlight positive elements of Brasilia. Lara (2010) notes that despite the inequalities, spatial exclusions, and frustration with the slow pace of necessary transformation, Brazilians have adapted to these challenges, and have brought Brazilian traditions with them while developing new urban practices. He specifies that after 50 years of development in Brasilia The superquadras are thriving with busy restaurants and bars every few blocks and noisy with children playing on the interstitial green spaces. What caused the change? The main factor is time. The small young trees planted at the city's inception have grown into large shady canopies. Stores that address the specific needs of the local inhabitants have thrived and multiplied. These changes highlight the fact that no city can be judged at its beginning. Instead, Brasilia, like all cities, needed time to develop and evolve (Lara, 2010). This suggests a high degree of resilience, be it perhaps unplanned. Furthermore, the ethnographic work of Marques et al. (2021) suggests that regardless of in which neighborhood of Brasilia children grow up they show a similar sense of belonging to the places in which they live. This would indeed reflect a sense of ownership of their location, which obviously can only emerge with time.

The construction of the capital Putrajaya also did not come without any critique or adversaries. Despite the public appearance of highly criticized deforestation to make way for the new capital, the design of Putrajaya aimed at using the available green to establish an ecologically friendly city with large green spaces and a big artificial lake in the center (Moser, 2010). Yet, soon after the inception, the national oil company Petronas took over a large part of the financing and planning, which resulted in a situation where the ecological focus was quickly vanishing. Instead, the resulting spatial design reflects the preference for a car-based city (Omar, 2004). In terms of the $8 \mathrm{Rs}$ one could argue that the relocation was not a bottom-up initiative and limited consultation with broader groups of stakeholders took place. Hence, the aspect of responsiveness in the design and construction has been limited.

In terms of spatial development Kozlowski et al. (2017) warn that the current urban regeneration and transformation of Kuala Lumpur Metropolitan Region, which includes the axis to Putrajaya, has the potential to lead to gentrification in a similar fashion in the entire region. Such a development would call for measures of closer connections to communities and more community participation in the urban regeneration process. In addition, the development of the metropole as a whole is positive for the economic power of the region, yet will also reinforce urban gentrification and a rapid increase in property prices. Both have a potential socio-spatial segregation effect. Reflecting from the $8 \mathrm{R}$ framework one could argue therefore that the development may lack a certain degree of robustness. It may lead to unintended and uncontrollable side effects, such as the price increases of properties.

Contrastingly, the public support for the relocation to Putrajaya is considerable. A large-scale survey executed and reported by Betria and Raju (2018) confirms this public support despite the fact that many respondents indicate having congestion problems having to travel to their new work place. Yet the decision of the Malaysian government is both trusted and respected. Hence, the relocation scores high on the aspect of respect, reliability and recognition as people also identify with the new capital as their symbolic center.

In South Korea, the development and growth has been slow in Sejong and it has not attracted many residents to relocate from Seoul. Sejong has a population of 351,007 as of 2020 and covers a geographic area of $465.23 \mathrm{~km}^{2}$, making it the least populous and smallest administrative division in South Korea. It has remained largely mono-functional, suggesting that any aim to create a lively city atmosphere will require a broad spectrum of development incentives, including opportunities for jobs and provision of cultural and educational facilities. Hence, in terms of self-sustainability and resilience it scores low.

Secondly, the ubiquity and smart nature of the capital remains contested. Hur et al. (2019) posit that the relocation has created bureaucratic inefficiencies simply because of the twocapital model. Despite ICT-enabled solutions, dubbed "Smart Work," these inefficiencies have actually remained intact and have not solved the challenges of information and ICT-based administration. Therefore, the relocation is not sufficiently robust in its processes, as organizational redundancies and cooperation problems persists. The result is that Sejong only functions as a "mini-capital." From a greening perspective the abundant presence of green areas instead of a polluted and congested city center, the presence and functionality modern and sustainable transportation systems, and an optimal social mix within the neighborhoods make the city quite liveable and identifiable, and can ensure that the city can function sustainably (Kang, 2012; Choi and Reeve, 2014). Hence, the aspect of recognition scores high.

Regarding the gentrification in Sejong one has to look at the existing studies of characteristics of gentrification in Seoul. Multiple type of gentrification exist: commercial gentrification (Ryu et al., 2020), housing gentrification (Kwon et al., 2017), restoration related gentrification (Lim et al., 2013). When gentrification requires displacement of people Lukens (2020) demonstrates the consistent relationship between metropolitanscale redevelopment and the process of repeat and chronic displacement in Seoul. Hence, it is very likely that displacement is a feature which occurs for the development of Sejong as well, be it however a rather hidden or undocumented feature.

Berlin's modernization has suffered from robustness and respect, given the high costs for the reconstructions and the emerging gentrification. The degree of participative approaches and direct benefits for stakeholders and affected citizens was not always sufficiently taken into account. The degree of responsiveness can also be critically evaluated, because Bonn actually had an operational government infrastructure and there was no immediate need to reduce or replace this. With regard 
to gentrification, there is an abundant amount of literature suggesting that Berlin's urban renewal policy since the unification (Siemer and Matthews-Hunter, 2017; Döring and Ulbricht, 2018). Its gentrification also often comes with involuntary displacement (Helbrecht, 2018).

Lahti's green strategy has a number of characteristics, which are remarkable in terms of the 8R framework. Besides having well-respected and well-documented strong aims regarding air quality, waste, green growth and eco-innovation, the governance strategy brings together brings together several programmes and plans including those focusing on smart, clean and circular economy, mobility, environment, energy, urban regeneration and citizen science. The central theme and vision for Lahti's 2018 city strategy is "Bold Environmental City," which did not come out of nowhere. It was built on several earlier pilot projects, with built-in reflexivity. Effects of the air quality plan of 1997 were closely monitored, and only after evaluation led to air quality regulations for the entire city. Such a reflexive and upgradable strategy is meaningful for the development of IKN as well.

With regard to gentrification there are various in-depth studies on gentrification and spatial inequalities in Finnish towns, such as (Jauhiainen, 1997; Ehrström, 2016). Specifically for Lahti the dissertation of Airas (2016) provides some general description in direct relation to upgrading of certain parts of the town, such as the waterfront area. Yet, the work of Hyötyläinen (2019) provides specific historical and socio-economic context for why gentrification has occurred only recently. Until recently OECD had listed Finland as the country with the least inequality. This changed however with the emergence of new technologies and industries, in particular related to telecommunication and ICT. The 2019 OECD statistics ${ }^{7}$ indicate an income inequality of 0.269 for Finland (OECD, 2021), where it used to be 0.211 in 1992 (reference: $0=$ complete equality; $1=$ complete inequality). According to the European statistics (EURES) in 2020 the region in and around Lahti has an employment rate which is below the national average, while the unemployment rate is above the national average, being one of the highest among all regions in Finland. Part of this may be due to the age structure as the share of those over 64 is above the national average. These kinds of statistics are no worrying per se, but suggest that certain types of businesses, such as family businesses, may be at risk, which may lead to spatial inequalities. New types of economic activities, such as tourism may thus be required to decrease the economic disparities.

With respect to Vancouver overall the greening efforts are highly praised and recognized globally. Yet, Affolderbach and Schulz (2017) also provide a critical note to this image. The argue that perhaps too much emphasis has been laid on becoming the first ranked city on international ranking schemes and performance indicators, at the expense of staying close to participatory approaches and changing the behavior of its citizens to meet the targets. So, whilst the political ambitions regarding participation are very visible in the policy process and setting the goals they are not always lived in reaching and monitoring the goals. In fact, citizens have expressed a certain level of

$\overline{{ }^{7} \text { https://data.oecd.org/inequality/income-inequality.ht }}$ disappointment in the leadership and action, despite the overall support for the GCAP. For the $8 \mathrm{R}$ framework this translate in a relatively high score for respect and recognition structures, but a lower value for the resilience and recognition processes and outcomes. O'neill and Affolderbach (2018) add that there may still be a large gap between the image of the city as leader of radical change toward greening and the actual reality which is not so radical.

Regarding gentrification, Mösgen et al. (2019) remark that privatization and demolition of the public housing complexes not only are a withdrawal of the state in securing equity in access and use of property, but also lead to direct and exclusionary displacement, and the forms of contestation and protest. Additionally, Jones (2020) describes displacement and gentrification because of transit oriented development strategies in Metro Vancouver. The transit oriented development strategies indeed create more opportunities for more energy-neutral mobility, yet also lead to gentrification because the rapid redevelopment of low-income rental housing follows the opening of a new rapid transit stations. Access to low- cost rental housing near public transit is important for the settlement process of refugees, making these newcomers particularly vulnerable to this form of gentrification.

Masdar City's original plans had to be scaled back due to lessons learned from continued assessments of the original concept (Griffiths and Sovacool, 2020), which altered the initial goals for reduction of $\mathrm{CO} 2$ and waste and drastically changed the manner in which the city aimed to develop. More specifically this meant only a $30 \%$ reduction in the embodied carbon of construction materials used in the construction of its buildings (relative to comparable buildings in Abu Dhabi), $40 \%$ reduction in the energy consumption of its buildings (relative to comparable buildings in Abu Dhabi) and 40\% reduction in the use of interior water (relative to comparable buildings in $\mathrm{Abu}$ Dhabi). Although not ideal, one has to remember that Abu Dhabi is the country with one of the highest greenhouse gas emissions per capita in the world. Yet, the stepping back and re-assessment of the rightfulness or appropriateness of the approach is a clear sign of reflexivity (Griffiths and Sovacool, 2020). Therefore also conclude that re-thinking the original goals given the current and upcoming changing realities may turn out to be the best outcome for Masdar City if it is truly to become a model for "eco-cities" of the future.

On the other hand, one could also question whether there was an explicit need for the construction, and whether this project was actually a particular response to this need. Desouza et al. (2020) describes the pathway and some difficulties with Masdar city. Masdar relied on a top-down planning approach, faced many economic struggles and did not attract as many as innovative industries as was hoped. Moreover, the city itself is still rather empty. Therefore, in terms of responsiveness the project would score low. On the other hand, since its inception the UAE has been able to gradually build research and development on renewable energy, which is now an internationally requested community. Hence, paradoxically, the initial non-economic project may turn into a profit making industry. From the $8 \mathrm{R}$ perspective this has an (perhaps unintended) built-in resilience. 
Cugurullo (2013) reflects on the, development of Masdar city as a manifestation of the nexus between eco-cities and sustainability ideology and shows how and whether such ideologies actually emerge in the manifestations of the practical development of new settlements. The conclusion of his critical reflection is that at the end of the day the Masdar City project turns out to be one with profit maximization, whereby the "social," component is not part of the agenda. He concludes therefore that despite image of the city being portrayed as constructed according to a broader sustainability ideology, project is covered is essentially dominated by economic logic.

The assessment of greening and gentrification of Birmingham is not overwhelmingly positive. Despite that fact that other rankings are currently referring to Birmingham as one of the greenest city based on the amount of green space, Mckendry (2017) argues that gentrification, a prioritization of the green consumption preferences of the middle class and use of scarce public funds for green amenities all remain serious concerns. Also, the critique on the implementation of the greening plans often refer to lack of progress, proper measuring indicators and the need for urban regeneration and revitalization. Hence, the struggles in Birmingham to make the city greener have also highlighted that greening cannot be isolated from making the city more socially equitable. Hence, a more holistic understanding of the relationship between social and environmental sustainability is necessary. In terms of the $8 \mathrm{Rs}$ one can therefore state that resilience and robustness of the greening polices are clearly at stake. The fact that the initiative www.greenerbirmingham.com emerged also provide evidence of more responsiveness and calls for more inclusion in the greening strategy.

\section{CONCLUSIONS AND RECOMMENDATIONS FOR FURTHER RESEARCH}

Especially post-independent countries often decide to relocate their capital city to a new location. This re-location comes often together with new ideas of what this capital city should present symbolically and with contemporary knowledge and insights in responsible and sustainable city development. Indonesia has also recently embarked on this strategy. The intentions for its new capital city - designed to be located in Kalimantan - are that it should become the greenest, smartest and sustainable capital city in the world. There are currently various designs for this new capital city, but it remains relevant to assess how and when such an ambitious goal is achieved. This research should thus support the further choices in the design and implementation of the relocation of the Indonesian capital city. How such intentions should become reality and what such intentions imply is the key objective of this article. We hypothesize that previous examples contain a certain degree of similarity, which can derive recommendations for future capital and green city designs. We further hypothesize that inclusion and diversity of such cities are vital. The fundament for this research lies in defining what actually constitutes both a capital city and green city. There are differing concepts related to both of these terms, which are dependent on location, ideology, culture and strategic planning. These differences influence the choices for the construction of a new capital city, which needs to be green and/or smart. The $8 \mathrm{R}$ analysis derived that the requirements for a relocation and a design for a capital and green city are multiple. Key requirements include the participation and inclusion, recognition of diversity, sustenance of cultural and landscape identity, sustainable balance of original and novel green and equal appreciation for both national and local needs and practices.

The conclusion is that new capital city designs and implementation of construction and planning activities inevitably require a fundamental and explicit framework when choosing to be green and responsible. Recognition and acknowledging aspects of spatial justice and inclusion in the design and execution processes is crucial. Furthermore, the design of greening should not be at the expense of existent tropical forest or cultural landscapes, or designed in complete isolation of spatial justice and affordable housing strategies. Concerning the specific nature of capital cities there are still additional requirements. Some of these are taking care of symbolic elements in the design of monuments, shapes and structure of the city representing national identity. Additionally there are functional elements, in order to preserve and maintain attractiveness and livability. Finally, there are social and cultural requirements, such as securing land tenure and land rights, securing diversity and relying on indigenous and local diversity and identity of cultures. This research and these findings is relevant for urban planning and design and for the wider field of land management.

Further research could extend the comparative assessments into additional capital and green cities, and also on the links between greening and social justice. The political realities of greening and capital relocations are often different from the more ambitious strategies and innovations in urban greening designs, such as those from Watson et al. (2020). In the greening design of the Indonesian capital city, the first indications are that the politicians are purposely opting for this more radical greening alternatives, but instead rely on more traditional or conventional greening strategies. This is however not to say that these options and choice may change in the future. It is exactly for this reasons that the last aspect of the $8 \mathrm{R}$ framework, reflectiveness, is crucial and why the development of the new capital city in Indonesia will need to be followed closely. Hereby the key interests are which socio-spatial decisions the Indonesian government will make in the process of city development, how and where local and (inter)national stakeholders will be involved and how fast the development and migration to the city will go. Following the experiences of other cities a gradual process with regular moments of reflexivity and close consultation with local and regional authorities is advisable in order to avoid regional disparities and inequalities. Of course, the new capital will be more than just symbolic. It also needs to be a liveable city where all kinds of citizens can enjoy their own quality of life and where national and international travelers will be happy to travel to. The experiences of Brasilia and Berlin amongst others has shown that gentrification is likely to occur if the development will be mono-functional, i.e., primarily focusing on 
the administrative capital requirements, or erecting monumental symbolic buildings only. Instead, the developments in Sejong and Lahti have shown that a gradual development with considerable involvement of public and private parties which develop multiple functions and services based on smart and green concepts is likely to be more successful.

An additional critical note may be that the choice for this $8 \mathrm{R}$ assessment framework, with the associated questions, might be biased toward favoring western or Eurocentric ideologies of how to govern cities. Some of the questions within the framework might be seen as favoring bottom-up governance structures and western types of new public management systems and associated discourses. On the other hand, the main aim was however not to critique non-European countries or administrations in particular countries wanting to change their capital city, or pointing to the problems of their greening strategies. Instead, the

\section{REFERENCES}

Abdullah, J., Ahmad, R., and Zainal, M. H. (2020). 25 years of putrajaya engineered landscapes: trend and perspectives. Environ. Behav. Proc. J. 5, 239-246. doi: 10.21834/ebpj.v5i15.2361

Affolderbach, J., and Schulz, C. (2017). Positioning vancouver through urban sustainability strategies? The greenest city 2020 action plan. J. Clean. Prod. 164, 676-685. doi: 10.1016/j.jclepro.2017.06.234

Airas, A. (2016). Historical Distinctiveness in the Changing Built Environment: Redevelopment Of Former Woodworking Waterfronts. Ph.D. Thesis. Faculty of Science, University of Helsinki, Helsinki, Finland.

Albino, V., and Dangelico, R. M. (2013). "Green cities into practice," in The Economy Of Green Cities, eds R. Simpson and M. Zimmermann (Dordrecht: Springer), 99-113. doi: 10.1007/978-94-007-1969-9_10

Amekwa, P. D., Dachaga, W., Chigbu, U. E., and De Vries, W. T. (2018). "Responsible land management: the basis for evaluating customary land management in Dormaa Ahenkro, in Ghana," in World Bank Conference on Land and Poverty (Washington, DC).

Angotti, T., and Irazábal, C. (2017). Planning Latin American cities: dependencies and "best practices." Lat. Am. Perspect. 44, 4-17. doi: $10.1177 / 0094582 X 16689556$

Báčová, T. (2012). Die Deutsche Hauptstadtfrage Bonn Versus Berlin: Der Beschluss Über Den Regierungs-Und Parlamentssitz Des Vereinten Deutschlands. Univerzita Karlova, Praha, Czech Republic.

Beatley, T. (2012). Green Cities Of Europe: Global Lessons On Green Urbanism. Washington, DC: Island Press. doi: 10.5822/978-1-61091-175-7

Bedford, R. (1992). Bonn or Berlin? Hauptstadt for reunited Germany. N. Z. J. Geograph. 94, 11-13. doi: 10.1111/j.0028-8292.1992.tb00432.x

Betria, I., and Raju, C. S. (2018). Society perception toward replacement government center from Kuala Lumpur to Putrajaya Malaysia. Sumatra J. Disast. Geograph. Geograph. Educ. 2, 73-79. doi: 10.24036/sjdgge.v2i2.155

Birmingham City Council Development Directorate (2013). Green Living Space Plan. Birmingham: Birmingham City Council.

Bourgon, J. (2007). Responsive, responsible and respected govenment: towards a new public administration theory. Int. Rev. Administr. Sci. 73, 7-26. doi: $10.1177 / 0020852307075686$

Bravo, E. (2019). Brasilia, The Smart City of The Past. Tomorrow.Mag. Tomorrow.City.

Breuste, J. (2019). Die Grüne Stadt: Stadtnatur Als Ideal, Leistungsträger Und Konzept Für Stadtgestaltung. Heidelberg: Springer-Verlag. doi: 10.1007/978-3-662-59070-6

Breuste, J., Artmann, M., Ioja, C., and Qureshi, S. (2020). Making Green Cities. Cham: Springer. doi: 10.1007/978-3-030-37716-8

Caldeira, T., and Holston, J. (2015). Participatory urban planning in Brazil. Urban Stud. 52, 2001-2017. doi: 10.1177/0042098014524461 application of the framework provides more transparency in the so-called "responsible" land management or governance claims, and derives inductively practical planning and governance problems which may occur, irrespective of the location of administration.

\section{DATA AVAILABILITY STATEMENT}

The original contributions presented in the study are included in the article/supplementary material, further inquiries can be directed to the corresponding author.

\section{AUTHOR CONTRIBUTIONS}

The author confirms being the sole contributor of this work and has approved it for publication.

Campbell, S. (1999). Capital Reconstruction And Capital Accumulation In Berlin: A Reply To Peter Marcuse. Oxford: Blackwell Publishers. doi: 10.1111/1468-2427.00185

Choi, H. S., and Reeve, A. (2014). Local identity in the form-production process, using as a case study the multifunctional administrative city project (Sejong) in South Korea. Urban Design Int. 20, 66-78. doi: 10.1057/udi.2013.38

Cochrane, A., and Jonas, A. (1999). Reimagining Berlin: world city, national capital or ordinary place? Eur. Urban Reg. Stud. 6, 145-164. doi: 10.1177/096977649900600204

Cochrane, A., and Passmore, A. (2003). Building a national capital in an age of globalization: the case of Berlin. Area 33, 341-352. doi: $10.1111 / 1475-4762.00040$

Cooper, T. L. (2012). The Responsible Administrator: An Approach To Ethics For The Administrative Role. New Jersey, NJ: John Wiley and Sons.

Costa, C., and Lee, S. (2019). The evolution of urban spatial structure in Brasília: focusing on the role of urban development policies. Sustainability 11:553. doi: $10.3390 /$ su11020553

Cugurullo, F. (2013). How to build a sandcastle: an analysis of the genesis and development of Masdar City. J. Urban Technol. 20, 23-37. doi: 10.1080/10630732.2012.735105

De Vries, W. T., and Chigbu, U. E. (2017). Responsible land management - concept and application in a territorial rural context. Fub. Flächenmanagement Und Bodenordnung 79, 65-73.

Desouza, K. C., Hunter, M., Jacob, B., and Yigitcanlar, T. (2020). Pathways to the making of prosperous smart cities: an exploratory study on the best practice. $J$ Urban Technol. 27, 3-32. doi: 10.1080/10630732.2020.1807251

Döring, C., and Ulbricht, K. (2018). "Gentrification hotspots and displacement in Berlin. a quantitative analysis," in Gentrification and Resistance, eds I. Helbrecht (Wiesbaden: Springer), 9-35. doi: 10.1007/978-3-658-20388-7_2

Eckardt, F. (2005). In search for meaning: Berlin as national capital and global city. J. Contemp. Eur. Stud. 13, 189-201. doi: 10.1080/14782800500212426

Ehrström, P. (2016). “Transformation and survival strategy-rural gentrification and social sustainability in gentrified metropolitan and urban ruralities, the case of Sundom, Vaasa, Finland," in Metropolitan Ruralities, eds K. Andersson, S. Sjöblom, L. Granberg, P. Ehrström, and T. Marsden (Bingley: Emerald Group Publishing Limited), 125-158. doi: 10.1108/S1057-192220160000023006

Faggio, G., Schlüter, T., and Vom Berge, P. (2018). The multiplier effect of the German Government move to Berlin. Lse Business Review.

FAO (2012). Voluntary guidelines on the responsible governance of tenure of land, fisheries and forests in the context of national food security. FAO, Rome, Italy.

Faria, R., and Pescatori, C. (2019). Brasília. The Wiley Blackwell Encyclopedia of Urban And Regional Studies. doi: 10.1002/9781118568446.eurs0029

George, R. B. S., Baker Jr, H. A., Abrahams, R. D., Katriel, T., Stallybrass, P., Traister, D., et al. (1999). Cultural Memory and the Construction of Identity. Detroit, MI: Wayne State University Press. 
Glaeser, E. L., and Kahn, M. E. (2010). the greenness of cities: carbon dioxide emissions and urban development. J. Urban Econ. 67, 404-418. doi: 10.1016/j.jue.2009.11.006

Griffiths, S., and Sovacool, B. K. (2020). Rethinking the future low-carbon city: carbon neutrality, green design, and sustainability tensions in the making of Masdar City. Energy Res. Soc. Sci. 62:101368. doi: 10.1016/j.erss.2019.101368

Grimes, A., Matlaba, V. J., and Poot, J. (2016). Spatial impacts of the creation of Brasília: a natural experiment. Environ. Plan. A 49, 784-800. doi: $10.1177 / 0308518 X 16684519$

Grimson, W., and Murphy, M. (2015). "The epistemological basis of engineering, and its reflection in the modern engineering curriculum," in Engineering Identities, Epistemologies And Values: Engineering Education And Practice In Context, Vol. 2, eds S. H. Christensen, C. Didier, A. Jamison, M. Meganck, C. Mitcham, et al. (Cham: Springer International Publishing), 161-178.

Hall, P. (2006). "Seven types of capital city," in Planning Twentieth Century Capital Cities, ed D. Gordon (London; New York, NY: Routledge), 1-7.

Helbrecht, I. (2018). "Gentrification and displacement," in Gentrification and Resistance, eds I. Helbrecht (Wiesbaden: Springer), 1-7. doi: 10.1007/978-3-658-20388-7_1

Hur, J.-Y., Cho, W., Lee, G., and Bickerton, S. H. (2019). The "Smart Work" Myth: how bureaucratic inertia and workplace culture stymied digital transformation in the relocation of South Korea's capital. Asian Stud. Rev. 43, 691-709. doi: $10.1080 / 10357823.2019 .1663786$

Hyötyläinen, M. (2019). Divided by policy: urban inequality in Finland. Faculty of Social Sciences, University of Helsinki, Helsinki, Finland.

Jauhiainen, J. S. (1997). Urban development and gentrification in Finland: the case of Turku. Scand. Hous. Plann. Res. 14, 71-79. doi: 10.1080/02815739708730423

Jones, C. E. (2020). Transit-oriented development and suburban gentrification: a "natural reality" of refugee displacement in metro Vancouver. Hous. Pol. Debate. doi: 10.1080/10511482.2020.1839935

Kahn, M. E. (2007). Green Cities: Urban Growth and the Environment. Washington, DC: Brookings Institution Press. doi: 10.2139/ssrn.933669

Kampamba, J., Kachepa, S., Nkwae, B., Matlhogojane, N. G., and Outule, T. (2018). Housing delivery to the low income in Botswana. Int. J. Hous. Markets Anal. 11:59. doi: 10.1108/IJHMA-06-2017-0059

Kang, J. (2012). A Study on the Future Sustainability of Sejong, South Korea's Multifunctional Administrative City. Focusing On Implementation Of Transit Oriented Development. Uppsala University, Uppsala, Sweden.

Kozlowski, M., Ujang, N., and Maulan, S. (2017). Urban regeneration to transform Kuala Lumpur metropolitan region. Pertanika J. Soc. Sci. Human. 25, 195-205.

Kwon, Y., Joo, S., Han, S., and Park, C. (2017). Mapping the distribution pattern of gentrification near urban parks in the case of gyeongui line forest park, Seoul, Korea. Sustainability 9:231. doi: 10.3390/su9020231

Lara, F. L. (2010). Brazilianization or Brasilianization? The first fifty years of Brasília. Portal Issue 5, University of Texas at Austin, United States.

Lauriano, W. (2015). Gentrificação Da Cidade Modernista: Brasília. Cadernos Metrópole 17, 155-178. doi: 10.1590/2236-9996.2015-3307

Lazar, D. (2005). Berlin-Washington, 1800-2000: Capital Cities, Cultural Representation, And National Identities. Cambridge: Cambridge University Press.

Leadbeater, C. (2016). Bonn- what became of Germany's cold war capital. The Telegraph.

Leem, Y., Han, H., and Lee, S. H. (2019). "Sejong Smart city: on the road to be a city of the future," in Computational Urban Planning and Management for Smart Cities. CUPUM 2019. Lecture Notes in Geoinformation and Cartography, eds S. Geertman, Q. Zhan, A. Allan, and C. Pettit (Cham: Springer), 17-33. doi: 10.1007/978-3-030-19424-6_2

Lim, H., Kim, J., Potter, C., and Bae, W. (2013). Urban regeneration and gentrification: land use impacts of the cheonggye stream restoration project on the Seoul's central business district. Habitat Int, 39, 192-200. doi: 10.1016/j.habitatint.2012.12.004

Lukens, D. (2020). Configurations of gentrification and displacement: chronic displacement as an effect of redevelopment in Seoul, South Korea. Urban Geograph. doi: 10.1080/02723638.2020.1742467

Marques, R. N., Müller, F., Kanegae, M. M., and Morgade, M. (2021). Two childhoods, two neighborhoods, and one city: utopias and dystopias in Brasilia. Children's Geogr. 19, 172-183. doi: 10.1080/14733285.2020.1772961
Mckendry, C. (2017). Greening Post-Industrial Cities: Growth, Equity, And Environmental Governance. New York, NY: Routledge. doi: $10.9774 /$ gleaf. 9781315773407

Momoh, J., and Benachir, M. (2018). Urban development and housing demolition in abuja city: the benefits of adopting the principles of sustainability. $J$. Good Govern. Sustain. Dev. Africa 4:2. Available online at: https://core.ac.uk/ download/pdf/323101522.pdf

Momoh, J., Opaluwah, A., and Albeera, H. (2018). Challenges facing Nigeria’s urban environment: the Abuja Case. J. Sustain. Dev. Afr. 20:2. Available online at: https://core.ac.uk/download/pdf/323101522.pdf

Moser, S. (2010). Putrajaya: Malaysia's new federal administrative capital. Cities 27, 285-297. doi: 10.1016/j.cities.2009.11.002

Mösgen, A., Rosol, M., and Schipper, S. (2019). State-led gentrification in previously 'un-gentrifiable'areas: examples from Vancouver/Canada And Frankfurt/Germany. Eur. Urban Reg. Stud. 26, 419-433. doi: $10.1177 / 0969776418763010$

Nasreldin, R., and Abdelfattah, D. (2020). Toward biophilic egyptian cities. the case of new administrative capital in Egypt. J. Urban Res. 35, 121-136. doi: 10.21608 /jur.2020.81521

OECD (2021). Income Inequality (Indicator). https://data.oecd.org/

Omar, D. B. (2004). The total planning doctrine and putrajaya development. Wit Trans. Ecol. Environ. 72, 91-910. Available online at: https://www.witpress. com/Secure/elibrary/papers/SC04/SC04009FU.pdf

O'neill, K., and Affolderbach, J. (2018). "Vancouver: leading green building transitions?," in Green Building Transitions, eds J. Affolderbach and C. Schulz (Cham: Springer), 99-132. doi: 10.1007/978-3-319-77709-2

Rawat, R. (2005). Capital City Relocation: Global-Local Perspectives In The Search For An Alternative Modernity. Unpublished Paper, Department Of Geography, York University, Toronto, Canada.

Rezende, R., and Heynen, H. (2020). "Brasilia and the utopia of an Egalitarian city: hidden shades of gender-oriented segregation," in P+ Arg Biennial Conference (Michigan).

Rossman, V. (2018). Capital Cities: Varieties and Patterns of Development And Relocation. Abingdon: Taylor and Francis. doi: 10.4324/97813157 35061

Ryu, H., Kim, D., and Park, J. (2020). Characteristics analysis of commercial gentrification in seoul focusing on the vitalization of streets in residential areas. Sustainability 12:8877. doi: 10.3390/su12218877

Sankaran, V., and Chopra, A. (2020). "Creating global sustainable smart cities (A case study of Masdar City)," in Journal Of Physics: Conference Series (Coimbatore: Iop Publishing). doi: 10.1088/1742-6596/1706/1/012141

Seitzhanova, A., and Nagy, H. (2018). The role of city tourism for regional development. Scientia Iuventa, 14.

Siemer, J., and Matthews-Hunter, K. (2017). The spatial pattern of gentrification in berlin. Praire Perspect. Geograph. Essays 19, 49-57. Available online at: https://www.ibgeographypods.org/uploads/7/6/2/2/7622863/gentrification of_berlin_excellent_background_reading_for_ib_geography.pdf

Timulak, L. (2014). "Qualitative meta-analysis," in The Sage Handbook Of Qualitative Data Analysis, ed U. Flick (London: SAGE Publications Ltd), 481-495. doi: 10.4135/9781446282243.n33

Watson, J., Robertson, A., and De Rosen, F. (2020). Designing by radical indigenism. Landscape Arch. Front. 8:148. doi: 10.15302/J-LAF-1-050019

Yoon, J., and Shin, U. (2019). "Effective application of urban renewable energy system for smart energy city: case study of Sejong 5-1 smart energy city," in Ieee Transportation Electrification Conference And Expo, Asia-Pacific (Itec Asia-Pacific: Ieee), 1-5. doi: 10.1109/ITEC-AP.2019.8903873

Conflict of Interest: The author declares that the research was conducted in the absence of any commercial or financial relationships that could be construed as a potential conflict of interest.

Copyright (๑) 2021 de Vries. This is an open-access article distributed under the terms of the Creative Commons Attribution License (CC BY). The use, distribution or reproduction in other forums is permitted, provided the original author(s) and the copyright owner(s) are credited and that the original publication in this journal is cited, in accordance with accepted academic practice. No use, distribution or reproduction is permitted which does not comply with these terms. 